\title{
PROVIDING LEGAL AID IN FACING CASES FOR UNDERPRIVILEGED COMMUNITIES AT THE RELIGIOUS COURTS OF SEMARANG CITY
}

\author{
Andjeng Pratiwi* \\ Paralegal at Legal Aid Center (LBH) UIN Walisongo, Semarang, Indonesia \\ *Email: andjengprtw10@gmail.com
}

This research aims to generate understanding through analysis related to legal regulations on legal aid and their application of Law 16/2011 concerning Legal Aid including several other implementing arrangements at the Semarang Religious Court. The form of the application of legal aid is implemented with the intention that people who are unable to obtain justice facilities through the implementation of legal aid by advocates. The provision of legal assistance at the Semarang Religious Court in cases of underprivileged communities has not run optimally as evidenced by advocates who handle a number of cases related to legal aid according to Law 16/2011 with a percentage of less than 10\% of all cases that have been received. . The ambiguity of legal norms becomes a juridical obstacle in the regulations that have the authority to provide legal aid between Law 20/2009 on Religious Courts and Law 16/2011 on Legal Aid, namely the lack of socialization of the Law on Legal Aid. So that the impact results in the "lack of public knowledge" of legal services; lack of institutional knowledge outside the court; and the lack of coordination between courts and institutions that

The Indonesian Journal of International Clinical Legal Education DOI: https://doi.org/10.15294/ijicle.v3i3.48271

Submitted: Dec 12, 2020 Revised: May 23, 2021 Accepted: July 29, 2021 Available online at https://journal.unnes.ac.id/sju/index.php/iccle (C) 2021 Authors. This work is licensed under a Creative Commons AttributionShareAlike 4.0 International License (CC BY-SA 4.0). All writings published in this journal are personal views of the authors and do not represent the views of this journal and the author's affiliated institutions.

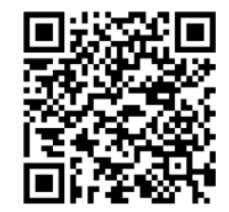




\section{Andjeng Pratiwi}

provide legal assistance; The limited budget available in the APBN to assist in the provision of laws is also an obstacle in handling a case if the case continues to the level of appeal, the level of cassation, and even the level of judicial review.

Keywords: underprivileged, legal aid, divorce, Semarang religious court

\section{INTRODUCTION}

Indonesia protects and recognizes human rights for each individual, including the right to obtain legal assistance. The implementation of the provision of legal assistance to the community in order to fulfill the characteristics of a legal state that protects, recognizes, and guarantees the rights of citizens who need access to justice and equality before the law. The guarantee of constitutionalism rights has not received proper attention, so Law 16/2011 concerning Legal Aid was made as a guide for the state in guaranteeing its citizens, especially for poor people in obtaining justice and equality facilities before the law. ${ }^{1}$ The right to legal aid has been guaranteed and accepted internationally in Articles 16 and 26 of the International Convention on Civil and Political Rights (ICCPR). Meanwhile, the provision of conditions for legal aid, such as matters relating to obtaining justice for those who cannot afford to pay an advocate fee, is regulated in Article 14 paragraph (3) of the ICCPR.

Article 1 paragraph (3) of the 1945 Constitution of the Republic of Indonesia states that the Unitary State of the Republic of Indonesia is based on the principle that the rule of law contains principles of upholding the law that do not conflict with the regulations that have been determined in the law, equality before the law, and the rule of law, and not a state based on power (machtsstaat). ${ }^{2}$ In the context of fulfilling the equality of every citizen before the law and in order to realize such an ideal concept, both of which can be implemented in close connection with facilities for justice, especially for the poor, the government is required to form a regulation that provides legal assistance.

Legal aid is the moral and professional responsibility of advocates, is individual, passive, limited to a formal approach and forms of legal aid

1 Yusup Syaefudin, “Implementasi Pemberian Bantuan Hukum Bagi Rakyat Tak Mampu di Jawa Tengah Berdasarkan Undang-Undang 16/2011 Tentang Bantuan Hukum", Jurnal Idea Hukum, Vol. 1, No.1, 2015, pp. 65-66.

2 Abdurrahman, "Beberapa Aspek Tentang Bantuan Hukum di Indonesia”, Jakarta: Penerbit UI, 1980, pp. 11-14. 
in the form of case assistance and defense in court. ${ }^{3}$ The term legal aid is used as a translation of two different terms, namely "Legal Aid" and "Legal Assistance". The term Legal Aid is usually used to show the meaning of legal aid in a narrow sense in the form of providing legal services to someone involved in a case free of charge, especially for those who are less fortunate. Meanwhile, the definition of Legal Assistance is used to show the meaning of legal aid by advocates who use honorarium. ${ }^{4}$ Legal assistance for the poor is carried out within the framework of efforts and goals that are broader than just legal services in court. Oriented to the realization of a rule of law based on the principles of democracy and human rights. Legal aid is an obligation within the framework to make them aware as legal subjects who have the same rights as other groups, are active, not limited to individuals and not limited to formal legal. ${ }^{5}$ In the society's view, until now, the facilities for justice are not the property or right of everyone, but belong to the rich, the paradigm is constructed as a result of the rampant behavior of most advocates or lawyers who tend to want to help clients if their services are paid for. Achmad Santosa said that facilities for justice are the people's ability to defend, fight for basic rights and obtain redress for rights that have been violated through formal and informal institutions that are in line with human rights standards. ${ }^{6}$

The community's facilities for justice are certainly related to Human Rights. ${ }^{7}$ In Indonesia, which adheres to the Pancasila ideology, human rights arrangements have been regulated in Law 39/1999 on Human Rights. The rights regulated and protected by Law 39/1999 on Human Rights include the right to obtain justice and the right to obtain legal assistance. In this case, the judiciary is an important institution that provides the fulfillment of these facilities. ${ }^{8}$ In addition to the judiciary, the police institution also plays an important role as a means of facilitating the fulfillment of facilities for legal justice, without

3 Ishariati Wika Utari, "Bantuan Hukum Secara Cuma-Cuma Bagi Tersangka atau Terdakwa Yang Tak Mampu”, Jurnal Ius Utopia Hukum-Kesejahteran, 2014, Vol. 2 No. 1, p. 112. See also Sarker, Shuvro Prosun. "Empowering the underprivileged: The social justice mission for clinical legal education in India." Clinical Legal Education in Asia. Palgrave Macmillan, New York, 2015, pp. 177-193.

4 Abdurrahman, “Aspek Aspek Bantuan Hukum di Indonesia”, Jogjakarta: Cendana Press, 1983, p. 34.

5 Ishariati Wika Utari, "Bantuan Hukum Secara Cuma-Cuma Bagi Tersangka atau Terdakwa Yang Tak Mampu”, Jurnal Ius Utopia Hukum-Kesejahteran, 2014, Vol. 2 No. 1, p. 115. Please also see Raharjo, Agus. "Discriminatory Policy Of The Indonesian Government Toward Advocate And Poor People, Funding Solution For Legal Aid." Indonesian Journal of International Law Vol. 13 No. 3, 2016, pp. 375394.

6 Achmad Sentosa, “Access To Justice Di Indonesia”, Jakarta: Ditjen Badilag MARI, 2012, pp. 17-18.

7 Pasal 1 angka (1) Undang-Undang 39/1999 Tentang Hak Asasi Manusia.

8 Pasal 17 Undang-Undang 39/1999 Tentang Hak Asasi Manusia. 
exception, facilities for the right to obtain legal assistance. ${ }^{9}$ The issue of legal aid in Indonesia is one of the problems that is still quite concerning and has not been solved satisfactorily. There are still many justice seekers who are economically incapable and marginalized communities cannot enjoy their right to obtain free legal aid. This relates to free legal aid which is a policy formed by the government which at the normative level is contained in Law 48/2009 concerning Judicial Power. ${ }^{10}$

Further actualization and concretization so that citizens who are unable to obtain free legal aid facilities are issued and enacted Law 16/2011 concerning Legal Aid, although many people are pessimistic about the effectiveness of the issuance of this law, efforts to fulfill justice facilities for citizens Economically disadvantaged communities are still very much needed in order to optimally address the provision of legal assistance to justice-seeking communities, especially for the poor and marginalized. The guarantee for everyone to get equal treatment before the law as a reflection of the principle of equality protection of the law and the principle of equal justice under the law (equal justice before the law) which is guaranteed in the 1945 Constitution in its development has been concreted in the form of the stipulation of the latest regulation, namely Law 16/2003. 2011 About Legal Aid. ${ }^{11}$ The interesting thing since the enactment of Law 16/2011 concerning Legal Aid is that legal aid providers will obtain legal aid services directly from the government and other legitimate sources, this provision is contained in the implementing regulations of Law 16/2011 concerning legal aid, namely Government Regulation 42/2013 regarding the Requirements, and Procedures for Legal Aid, as well as the Distribution of Legal Aid. ${ }^{12}$

The state recognizes the existence of economic, social, cultural, civil and political rights for the poor, so constitutionally the poor have the right to be represented and defended both inside and outside the court (access to legal counsel). Legal aid for the poor is contained in Article 34 paragraph (1) of the 1945 Constitution. So legal aid is the right of the poor that can be obtained without paying (pro bono publico) as an elaboration of equal rights before the law. ${ }^{13}$ Article 34 paragraph (2) and paragraph (4) of the 1945 Constitution stipulates that the state shall develop a social security system for all people and empower the weak and underprivileged in accordance with human dignity as regulated in the

9 Pasal 18 ayat (4) Undang-Undang 39/1999 Tentang Hak Asasi Manusia.

10 Pasal 56 ayat (1) dan ayat (2) Undang-Undang 48/2009 Tentang Kekuasaan Kehakiman.

11 Pasal 12 Undang-Undang 16/2011 Tentang Bantuan Hukum.

12 Pasal 18 PP 42/2013 tentang Persaratan dan Tata Cara Bantuan Hukum serta Penyaluran Bantuan Hukum.

13 Fransiskus Hendro Winata, "Pro Bono Publico: Hak Konstitusional Fakir Miskin Untuk Memeroleh Bantuan Hukum”, Jakarta: PT Gramedia Pustaka Utama, 2009, pp. 39-40. 
UUBH. ${ }^{14}$ Thus, the issue of legal aid services is no longer an excuse for arbitrarily refusing to provide legal aid to poor groups of citizens. If a legal aid institution refuses to provide legal aid, it must be done with reasons that can be legally accounted for, for example the reason for refusing a request for legal aid submitted by a poor member of the community regarding a nebis in idem case.

In relation to the study in the judiciary, I will examine the Religious Courts Class IA Semarang City, which has absolute authority in examining, adjudicating, and deciding cases of marriage, inheritance, grants, wills, endowments, shadaqoh and sharia economics in the implementation of legal aid for citizens. poor people. This authority is already contained in Law 16/2011 concerning Legal Aid along with all other implementing regulations including PP 42/2013 concerning Terms and Procedures for Legal Aid and Distribution of Legal Aid, as well as SEMA 10/2010 concerning Guidelines for Legal Aid, as well as with the issuance of PERMA 1/ 2014 concerning Guidelines for Providing Legal Services for Underprivileged People in Courts.

From the background that has been described, several problems can be formulated that will be discussed, namely: First, what are the regulations related to legal aid in Indonesia; Second, how are the authorities and duties of the Semarang City Religious Court regarding legal aid for the underprivileged; Third, how is the legal aid mechanism for the underprivileged at the Religious Courts of Semarang City; Fourth, what are the barriers to providing legal aid to underprivileged communities at the Religious Courts of Semarang City?

\section{REGULATIONS REGARDING LEGAL AID IN INDONESIA}

In Indonesia itself, legal aid as a legal institution was initially unknown in the traditional legal system. Legal aid has only been known in Indonesia since the entry or implementation of the Western legal system in Indonesia. Based on the principle of concordance, among others, regulations concerning the composition of the judiciary and judicial policy (Reglement of de Regterlijke Organisaticen het beleid der Justitie). ${ }^{15}$ It was in this legal regulation that for the first time an "Advocacy Institution" was regulated so that it can be assumed that legal aid in a formal sense only started in Indonesia around this time. ${ }^{16}$ Looking

14 Irwan Wahyu Pudjiarto, "Pelaksanaan Pemberi Bantuan Hukum Dikaitkan Dengan Undang-Undang 16/2011 tentang Bantuan Hukum”, USU Law Journal, Vol.3, No.2, 2015, pp. 87-88.

15 Abdurrahman, “Aspek-Aspek Bantuan Hukum di Indonesia”, Jakarta: Cendana Press, 1983, pp. 40-41.

16 Fransiskus Hendro Winata, "Bantuan Hukum: Sebuah Hak Asasi Manusia Bukan Belas Kasihan”, Jakarta: PT. Elex Media Komputindo, 2000, pp. 22-25. 


\section{Andjeng Pratiwi}

at the history and development of legal aid in Indonesia from the Legal Certainty theory, because at the beginning of independence, Indonesian law was still influenced by Dutch law, and the treatment of the population was classified into three groups (European, Foreign Eastern and Bumi Putra groups), it is clear that legal certainty has not guaranteed the existence of legal certainty for the poor, especially at that time with different groups also had implications for the justice system. With the enactment of Law 14/1974 which was amended by Law 48/2009 concerning Judicial Powers, legal assistance for people seeking justice, especially the poor or underprivileged, will be accommodated in Law 48/2009 concerning Judicial Power, public justice is more guaranteed and legal protection for the community unable to be accommodated with the ratification of SEMA 10/ 2010 concerning Guidelines for the Provision of Legal Aid, in which every court institution is formed a Legal Aid Post (POS BAKUM) as a forum to assist underprivileged communities in facilitating justice.

The juridical basis for legal aid at the time of independence is Herziene Inlandsch Reglement (HIR) Article 250 which provides for the provision of legal assistance for defendants who are threatened with the death penalty or life imprisonment. Then, Law 14/1970 was promulgated on the Basic Provisions of Judicial Power. The current regulations governing legal aid as a guarantee of justice in protecting the rights of the poor or underprivileged are:

1. Law 8/1981 on the Criminal Procedure Code. Regarding the regulation of legal aid in the Criminal Procedure Code, it can be seen in the provisions of the following articles:

a. Article 56 paragraph (1) reads: "In the event that a suspect or defendant is suspected or charged with committing a criminal act which is punishable by the death penalty or a sentence of fifteen years or more or for those who are unable to do so, they are threatened with a sentence of five years or more which is not have their own legal advisors, the officials concerned at all levels of examination in the judicial process are obliged to appoint legal counsel for them.

b. Article 56 paragraph (2) reads: "Legal advisors who are appointed to act as referred to in paragraph (1), provide assistance free of charge".

c. Article 114 reads: "A person is suspected of committing a criminal act before the commencement of examination by an investigator, the investigator is obliged to notify his rights to obtain legal assistance or he must be accompanied by legal counsel in his case".

In the Criminal Procedure Code, especially in chapter VII Articles 69 to 74, it contains provisions regarding Legal Aid. In the articles of the Criminal Procedure Code, it is regulated regarding the right to 
obtain legal assistance, when providing legal assistance, supervision of the implementation of legal aid and the form of legal aid. The provisions contained in the Criminal Procedure Code regarding legal aid if examined do not yet exist explicitly regulate legal aid for the underprivileged, the articles regarding legal aid are only general in nature regarding the right for justice seekers to obtain legal assistance for people involved in criminal acts. Thus the regulation of legal aid contained in the Criminal Procedure Code does not guarantee a sense of justice for the poor, it is still limited to legal certainty, that in the sense of the existence of general rules that make a person or legal subject know what actions may or may not be carried out, and with the existence of With these general rules, one can know what the state may charge or do to individuals.

2. Law 18/2003 on Advocates

The background of the enactment of Law/2003 on Advocates can be seen in the preamble to this law where it is stated that judicial power which is free from all interference and influence from outside, requires an advocate profession that is free, independent and responsible for the implementation of an honest, fair and fair trial. have legal certainty for all justice seekers in upholding the law, truth and human rights. The regulation regarding free legal aid in the Advocate Law is regulated in Article 1 point 9 which explains the meaning of legal aid. Legal Aid is legal services provided by advocates free of charge to clients who can't afford it. Then it is regulated in Article 22 paragraph (1) which explains that advocates are obliged to provide legal assistance to justice seekers who can't afford. And in paragraph (2) the provisions regarding the requirements and procedures for providing free legal aid are further regulated by a Government Regulation.

3. Law 50/2009 on Religious Courts

By evaluating the condition of the people who lack knowledge of the law, especially for justice seekers who fall into the category of people who are financially underprivileged to pay for the services of an advocate. With the promulgation of Law 50/2009 concerning the second amendment to Law 7/1989 concerning Religious Courts, the Religious Courts can make new breakthroughs in providing facilities for people seeking justice who are considered economically incapable as regulated in Article 60B of Law 50/2009. It is stated in paragraph (1) "Everyone who is involved in a case has the right to obtain legal assistance" further in paragraph (2) "The state bears the costs of the case for justice seekers who cannot afford" and in paragraph (3) it is stated "The party who is unable as mentioned in paragraph (2) must attach a certificate of incapacity from the kelurahan where the concerned domicile is". 
Andjeng Pratiwi

This facility for the poor to obtain justice is also accommodated in the Religious Courts with the establishment of Legal Aid Posts, this is as stated in Article 60C of Law 50/2009 concerning Religious Courts which reads:

a. Paragraph (1) In every Religious Court, a Legal Aid Post is established for justice seekers who are unable to obtain legal assistance.

b. Paragraph (2) Legal aid as referred to in paragraph (1) is provided free of charge to all levels of the judiciary until all decisions on the case have permanent legal force.

c. Paragraph (3) Legal aid and Legal Aid Post as referred to in paragraph (1) and paragraph (2) shall be carried out in accordance with the laws and regulations.

With the accommodation of justice facilities for people who cannot afford justice in Law 50/2009 on Religious Courts, in accordance with the theory of justice, the law has guaranteed that everyone, regardless of the status of the rich and poor, has the same position before the legal process in court in fighting for their rights. obtain justice, as well as the existence of equal legal protection and certainty for underprivileged communities in filing claims for their rights, from the lowest court level to the highest court level, namely the Supreme Court of the Republic of Indonesia.

4. Law 51/2009 concerning State Administrative Court.

Legal assistance in state administrative courts is contained in Law 51/2009 in Article 57 which explains the right to be accompanied and represented by a proxy. Then, referring to Law 5/1986 Article 60 , it is explained that the dispute is free of charge on the condition that evidence is not available. Furthermore, Article 61 explains the obligation of the court in determining the application for litigation free of charge.

5. Law 16/2011 concerning Legal Aid.

In Article 28H paragraph (2) of the 1945 Constitution it is stated that everyone has the right to receive special facilities and treatment to obtain equal opportunities and benefits in order to achieve equality and justice, which in the Law on Legal Aid hereinafter abbreviated as UUBH is implied in the rules regarding the application for Aid Recipients. Law in the provisions of Chapter VI Terms and Procedures for Providing Legal Aid Article 14.

Broadly speaking, Law 16/2011 concerning Legal Aid regulates the procedure for providing free legal aid to Legal Aid Recipients, which includes poor people or groups of people who are facing legal problems. Legal Aid Providers who have met the requirements of this UUBH have the right to recruit advocates, paralegals, lecturers, and students of the Faculty of Law in providing legal aid services which include litigation and non-litigation. After 
the UUBH was promulgated, the Ministry of Law and Human Rights enacted Permenkumham 3/2013 concerning Procedures for Verification and Accreditation of Legal Aid Institutions that provide legal assistance to poor people or groups of people. This was made to implement the provisions of Article 7 paragraph (4) UUBH.

Observing Law 16/2011 concerning Legal Aid, related to the regulation regarding the provision of legal aid for the underprivileged/poor community, it has been accommodated in detail, where even someone who cannot read and write can apply for legal assistance assisted by legal aid providers as long as they meet the requirements according to the provisions stipulated in the law. apply. Likewise, regarding legal aid providers, the requirements for legal aid organizations that are allowed and entitled to provide legal aid have been determined, in other words, not all legal aid institutions can provide legal aid for the underprivileged/poor. This is in accordance with the theory of legal certainty and legal protection, where people who are legally blind have been confirmed to receive legal assistance, as well as automatically the rights of justice seekers to obtain justice are fulfilled in accordance with the principle of legal aid must prioritize the principles of justice and equality of treatment before the law.

\section{THE AUTHORITY AND DUTIES OF THE RELIGIOUS COURTS OF SEMARANG CITY REGARDING LEGAL AID FOR UNDERPRIVILEGED COMMUNITIES}

The Religious Courts is one of the judicial environments under the Supreme Court which was formed based on Law 7/1989 which is intended for Muslim justice seekers to settle certain cases. In the explanation of Article 10 paragraph (1) of Law 14/1970, that religious courts are called special courts, because the parties (subjects) and objects of the case are certain. This is in accordance with one of the principles in proceedings in religious courts, namely the principle of Islamic Personality that those who are subject to and can be submitted to the authority of the religious court environment are only those who claim to be followers of the Islamic religion. For adherents of other religions are not subject to or cannot be forced to submit to the Religious Courts, except for non-Muslims of their own volition to submit to Islamic law. ${ }^{17}$

17 Fatharlillah, "Plurality of Shariah Banking Dispute Settlement Methode in Indonesia", Jurnal IUS (Kajian Hukum dan Keadilan), Vol. 2, No. 3, 2014, p. 542. 
The authority of the Religious Courts consists of relative authority and absolute authority. ${ }^{18}$

\section{Relative Authority}

The relative power (competence) of the Religious Courts is the power over the legal area in the sense that it is different from the power of the Court of the same level. Those relating to the jurisdiction and the Court are different (standing) according to the applicable law. This relative competence is regulated in Law 7/1989 Article 4 paragraph (1) which states that the Religious Courts are domiciled in the municipality or in the district capital, and their jurisdiction covers the municipality or district. However, in the explanation of Article 4 paragraph (1) there is an exception, this exception can be in the form of a smaller legal allocation from the city or district. When viewed from the Theory of Legal Certainty, the issue of relative authority or competence is very important for justice seekers because it involves the legal jurisdiction of the Semarang Religious Court where someone should file a claim for their rights. With this relative authority, it guarantees legal certainty for justice seekers to file a lawsuit, because a lawsuit application will be accepted, examined and decided by the court if the plaintiff or applicant who filed a lawsuit or application is in the jurisdiction or jurisdiction of the Semarang Religious Court, except for the law. the law dictates otherwise.

\section{Absolute Authority}

Absolute power (competence) is absolute power with regard to the type of case, or the type of court or level of court that is entitled to a case settlement in difference to the type of case or type of court or other level of court. This issue of absolute authority becomes very urgent for justice seekers where when viewed from the theory of legal certainty and the theory of justice, it will be clear that the Religious Courts adhere to the principle of Islamic personality, where litigants in the Religious Courts are for justice seekers, especially people who are Muslim, who will file their legal problems in accordance with the authority of the Religious Courts as stated in Article 49 of Law 3/2006, so that their lawsuit applications will not be rejected or not accepted because they are hampered by absolute authority.

The task of the Semarang Religious Court in accordance with the provisions of Article 2 in conjunction with Article 49 of Law 3/2006 concerning Amendments to Law 7/1989 concerning Religious Courts is to examine, decide, and settle cases at the first level between people whose religion is Islam in the fields of:

18 Rayhan Rasyid, “Hukum Acara Peradilan Agama”, Jakarta: Raja Grafindo Persada, 2007, p. 26. 


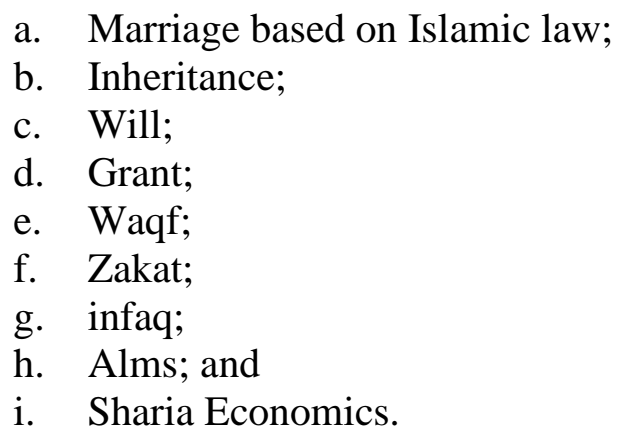

\section{LEGAL AID MECHANISM FOR UNDERPRIVILEGED COMMUNITIES AT THE RELIGIOUS COURTS OF SEMARANG CITY}

The implementation of Legal Aid in the Religious Courts as well as in the Semarang Religious Courts is based on the provisions of Article 56 of Law 48/2009 concerning Judicial Power and Article 60B of Law 50/2009 concerning the second amendment to Law 7/1989 concerning Religious Courts which states that anyone who involved in a case have the right to obtain legal assistance and the state bears the costs of the case for justice seekers who cannot afford it. Article 57 paragraph (1) of Law 48/2009 and Article 60C paragraph (1) of Law 50/2009 also stipulates that in every court a Legal Aid Post is established for justice seekers who are unable to obtain legal assistance. In paragraph (2) it is stated that the legal aid is provided free of charge at all levels of the judiciary until the decision on the case has obtained permanent legal force. ${ }^{19}$

Then the juridical provisions were concreted by the Supreme Court by issuing a Circular Letter on Guidelines for the provision of legal aid in the General Courts, State Administrative Courts and Religious Courts. Especially in the Religious Courts guided by SEMA 10/2010 which is the scope of legal assistance within the Religious Courts is "legal assistance in civil cases including prodeo cases, organizing mobile courts and providing Legal Aid Posts in the Religious Courts free of charge for the poor, SEMA 10/2010 has been further refined with the ratification of PERMA 1/2014 concerning Guidelines for Providing Legal Services for Poor People in Court. With the ratification of PERMA 1/2014, SEMA

19 Asmadi, Erwin, and Rachmad Abduh. "The Role of Legal Aid at the Muhammadiyah University of North Sumatra in Divorce Prevention." International Journal Reglement \& Society (IJRS) Vol. 2 No. 1, 2021, pp. 11-16. Please also compare with Libra, Robert, and Wilda Arifalina. "Right of Litigation Legal Aid Providers Other than Advocates in Pekanbaru Religious Court." Prosiding CELSciTech 3, 2018, pp. 93-97. 
$10 / 2010$ is declared no longer valid. In the general provisions of PERMA $1 / 2014$ article 1 number (1) it is stated that the provision of legal services for the underprivileged in court includes services for waiving court fees (Prodeo), hearings outside the court building and the Court Standard Post in the General Courts, Religious Courts, and the State Administrative Court. The provision of waiver of court fees can be as needed in each fiscal year, and applies to each level of justice individually and cannot be provided for all levels of justice at once. This means that the case at the first level does not simultaneously cover the appeal level and so on, both including the procedures and costs. The procedure and mechanism for the waiver of court fees at the Semarang Religious Court refers to the Circular Letter of the Director General of Badilag of the Supreme Court of the Republic of Indonesia 0508a/DjA/HK.00/III/2014 dated March 24, 2014 concerning Technical Instructions for the Implementation of Regulation of the Supreme Court of the Republic of Indonesia 1/2014 concerning Guidelines Legal Services for the Poor in Courts.

In the event that the application for waiver of court fees is granted, the letter of determination from the Chairperson of the Religious Courts is made in 3 (three) copies each for the Petitioner, the Registrar/Secretary as the Budget User Proxy (KPA) and for the case file. Based on the Decree of the Head of the Religious Courts, the Registrar/Secretary as the Budget User Authority (KPA) makes a decree to charge court fees to the state budget by stating the amount of the budget charged to the state; (the amount of the fee is in accordance with the Decree of the Head of the Religious Courts concerning the Payment for the Fee for the settlement of cases at the Semarang Religious Court). By examining the provisions for exemption from case financing for underprivileged communities in the circular letter of the Director General, it proves that the government, in this case the Supreme Court through the Religious Courts, has provided legal certainty for the public to obtain justice facilities by litigation financed by DIPA in accordance with applicable regulations.

Implementation of Legal Aid as intended by Law 16/2011 concerning Legal Aid, that the funds for providing assistance as mandated by the Law on legal aid are sourced from DIPA of the Ministry of Law and Human Rights. That of the cases that entered the Semarang Religious Court during 2015 to August 2016 only a few LBH and OBH provided legal assistance at the Religious Courts, including (LBH Pelangi, Padi, Graffiti and LBH Apik) the percentage of cases handled through grants Laws originating from the Ministry of Law and Human Rights range from 5 to 15 cases per $\mathrm{LBH}$, so it is very minimal when compared to the needs of the poor who need legal assistance, compared to the number of cases that are entered in the Semarang Religious Court. When viewed from a sense of justice and legal certainty, it is said that a sense of justice for the poor, who have litigation through the Semarang 
Religious Court, has not been fulfilled as the hopes and aspirations of the state protect all people and provide equal treatment before the law, and seen from legal certainty, that the Law Legal aid does not guarantee that the poor can easily facilitate justice through the courts, because the Religious Courts only provide limited funds for the costs of court proceedings, not including the costs of assistance by Legal Aid Institutions or Legal Aid Organizations.

The Legal Aid Post (Posbakum) is a new institution in the Religious Courts, its existence is an implementation of the mandate of Article 60C paragraph (1) of Law 50/2009, the second amendment to Law 7/1989 concerning Religious Courts which requires the establishment of Legal Aid Posts in every Religious Court/Syariah Court. 'iyah for justice seekers who are unable to obtain legal assistance. From the PERMA provisions, when examined at the Semarang Religious Court, in reality the Posbakum on duty at the Semarang Religious Court has not fully performed the services as stated in the PERMA above, because the Posbakum on duty at the Semarang Religious Court is still limited to assistance in making claims or requests for the community. who will file a lawsuit or application at the Semarang Religious Court, as well as consultation on legal issues.

While there is no information about legal institutions or legal organizations that provide assistance to the poor in proceedings at the Religious Courts, this is because there is no cooperation between legal aid institutions that have been certified and have the right to provide legal aid with the legal aid post in the area. court. Likewise with the provision of mentoring services, OBH who are on duty at the Semarang Religious Court do not provide assistance to people who are unable to carry out their proceedings in front of a court session. This fact causes the facilities to obtain legal assistance for underprivileged communities, especially assistance by advocates from Legal Aid Organizations or Legal Aid Institutions in court, while the legal aid law provides facilities in the form of such assistance. In fact, the role of advocates, especially OBH or $\mathrm{LBH}$ advocates, in assisting underprivileged citizens in front of court hearings is very beneficial.

\section{BARRIERS TO PROVIDING LEGAL AID FOR UNDERPRIVILEGED COMMUNITIES IN THE RELIGIOUS COURTS OF SEMARANG CITY}

\section{Juridical Barriers}

One of the government's efforts in the context of fulfilling justice facilities for underprivileged communities, the government through the 
Supreme Court and the lower courts provides legal aid programs or legal services for economically disadvantaged communities, in the Religious Courts in providing legal assistance the juridical basis refers to the provisions Article 56 of Law 48/2009 concerning Judicial Power and Article 60B of Law 50/2009 concerning the Second Amendment to Law $7 / 1989$ concerning Religious Courts state that everyone involved in a case has the right to obtain legal assistance and the state bears the costs of the case for justice seekers who cannot afford it. Article 57 of Law 48/2009 and Article 60C of Law 50/2009 also stipulates that in every court a Legal Aid Post is established for justice seekers who are unable to obtain legal assistance. In the next paragraph it is stated that the legal aid is provided free of charge at all levels of the judiciary until the decision on the case has obtained permanent legal force.

As a form of concretization of the service in question, POSBAKUM services are established within the Religious Courts along with other supporting facilities and infrastructure as an effort to ensure the optimization of facilities for the poor and marginalized within the Religious Courts/Syar'iyah Courts, both of which include assistance in terms of making lawsuits/applications and jinayat cases, prodeo cases and circuit courts, one unit with the costs. POSBAKUM is a center for legal aid services in the form of providing information, consulting, advising and making lawsuits/applications in the Religious Courts, born since Law 50/2009 concerning the Second Amendment of Law 7/1989 on Religious Courts. POSBAKUM is one of "Justice for All" which is justice for everyone aiming to provide services in the form of providing legal advice, counseling and making lawsuits for those who do not know about legal issues and cannot afford a lawyer to solve their family law problems in the Religious Courts.

a. UUBH is a law that specifically provides facilities for legal aid institutions and community organizations to actively participate in providing legal aid services for the poor based on the consideration that the implementation of legal aid is oriented towards the realization of just social change. Where legal aid providers (LBH and Orkesmas), have the right to: recruit lawyers, paralegals, lecturers, and law faculty students;

b. perform Legal Aid services;

c. organize legal counseling, legal consultation, and other program activities related to the implementation of Legal Aid;

d. receive a budget from the state to implement Legal Aid under this law;

e. issue an argument or statement in defense of the case for which he is responsible in a court session in accordance with the provisions of the legislation.

On the one hand, the existence of Law 16/2011 has resulted in a reduction in the space and operational authority of the judiciary under the 
Supreme Court. There was also a transfer of Posbakum funds to the Ministry of Law and Human Rights. This reflects the legal justice of the existing judicial institutions, due to the conflicting dualism of regulations between Law 50/2009, Law 48/2009, Law 49/2009, and Law 16/2011. So far, the implementation of Posbakum has been successfully implemented by the Supreme Court and its staff, but with the enactment of Law 16/2011 it will be transferred to the Ministry of Law and Human Rights. This means that the DPR when discussing the bill on legal aid related to Posbakum did not fully see the substance of Law 50/2009, Law 48/2009, and Law 49/2009 which regulates Posbakum and legal aid for poor people who have litigation in court. The substance of Article 60 of the Religious Courts Law clearly states that "everyone involved in a case has the right to obtain legal assistance". This is where then a counterproductive legal loophole occurs with the birth of Law 16/2011.

If in such a case the DPR is the benchmark for considering the birth of a new law, even though the issue of legal aid itself is regulated by a law, then of course it can be faced with legal divisions and an unnatural perception of the DPR.

\section{Non-Judicial Barriers}

As for the non-juridical obstacles referred to in the context of the effectiveness of providing legal aid services that can be carried out directly by the Supreme Court and the judicial institutions below it, including the Religious Courts in it, namely, the lack of socialization of Law 16/2011 concerning Legal Aid, so that it has an impact on:

a. Lack of Public Knowledge of legal services

In this case, what is meant is Community Knowledge, which so far does not know that there are other institutions outside the court that are authorized to provide legal aid services for the underprivileged. The public only knows that so far only the judiciary has provided these facilities, namely through the POSBAKUM service available at the judiciary. As a result, in terms of quantity, the public tends to request submissions to the judiciary, while on the one hand the judiciary itself has problems with the availability of budget funds.

b. Lack of knowledge of institutions outside the court.

In this case, what is meant is the lack of knowledge of legal aid institutions, legal aid organizations and so on about the mechanisms and administrative requirements to become part of an institution that can provide legal aid services or legal aid providers, which is abbreviated as $(\mathrm{PBH})$ to the poor. In this case related to the mechanism and strict administrative requirements to become a legal aid institution, legal aid organization and so on that can provide legal aid services so that it can be called $\mathrm{PBH}$, a legal aid organization must follow the verification process carried out by the government. If the $\mathrm{OBH}$ succeeds in meeting all the requirements needed during 


\section{Andjeng Pratiwi}

the verification process, the government will declare the $\mathrm{OBH}$ passed the verification, and the accreditation value will be determined. An accredited $\mathrm{OBH}$ can be considered a $\mathrm{PBH}$ and can provide legal aid services in accordance with the Legal Aid Act. In addition, many $\mathrm{PBH}$ institutions that have provided legal aid services admit that they are reluctant to make reimbursements to BPHN, considering the quite complicated requirements that must be met.

c. Lack of coordination between legal aid providers and the courts.

The court is not aware of legal aid organizations that have passed verification and there has never been any official coordination or delivery regarding legal aid organizations that have passed verification and provide legal aid services to the poor without charging fees because the government has provided the budget through BPHN. The court only knew about Posbakum who had been in court.

\section{CONCLUSION}

The regulation of legal aid for the poor in Law 8/1981 concerning the Criminal Procedure Code (KUHAP) is only limited to criminal acts punishable by 5 years or more. Whereas in Law 18/2003 concerning Advocates, Law 50/2009 concerning Religious Courts, Law 51/2009 concerning State Administrative Courts, Law 16/2011 concerning Legal Aid, the regulation regarding legal aid for poor people who have litigation in court can cover all fields. case. Furthermore, the implementation of Law 16/2011 concerning Legal Aid in the Religious Courts of Semarang is still limited to legal services as regulated by PERMA 1/2014 concerning Guidelines for the Provision of Legal Aid services for underprivileged communities in court, namely, limited to the establishment of POSBAKUM, mobile court services (trials outside the building) and exemption from court fees for economically disadvantaged communities. Meanwhile, legal aid as regulated in Law 16/2011 concerning Legal Aid is carried out by several Legal Aid Organizations $(\mathrm{OBH})$. The obstacles faced in the implementation of Law 16/2011 concerning Legal Aid for the poor at the Semarang Religious Court, which include juridical obstacles, namely the blurring of legal norms and non-juridical barriers, including lack of socialization, limited budget for legal assistance for the underprivileged. 


\section{REFERENCES}

Abdurrahman, A. (1980). Beberapa Aspek Tentang Bantuan Hukum di Indonesia. Jakarta: Penerbit UI.

Abdurrahman, A. (1983). Aspek Aspek Bantuan Hukum di Indonesia. Jogjakarta: Cendana Press.

Asmadi, E., \& Abduh, R. (2021). The Role of Legal Aid at the Muhammadiyah University of North Sumatra in Divorce Prevention. International Journal Reglement \& Society (IJRS), 2(1), 11-16.

Fatahullah, S. H. (2014). Plurality Of Shariah Banking Dispute Settlement Method In Indonesia. Jurnal IUS Kajian Hukum dan Keadilan, 2(3).

Libra, R., \& Arifalina, W. (2018). Right of Litigation Legal Aid Providers Other than Advocates in Pekanbaru Religious Court. Prosiding CELSciTech, 3, 93-97.

Mardani, M. (2009). Hukum Acara Perdata Peradilan Agama dan Mahkamah Syareah. Jakarta: Sinar Grafika.

Pujiarto, I. W., Kalo, S., Putra, M. E., \& Ikhsan, E. Pelaksanaan Pemberi Bantuan Hukum Dikaitkan dengan Undang-undang No. 16 Tahun 2011 Tentang Bantuan Hukum. USU Law Journal, 3(2), 87-96.

Raharjo, A. (2016). Discriminatory Policy Of The Indonesian Government Toward Advocate And Poor People, Funding Solution For Legal Aid. Indonesian Journal of International Law, 13(3), 375-394.

Rasyid, R. (2007). Hukum Acara Peradilan Agama. Jakarta: Raja Grafindo Persada.

Saefudin, Y. (2015). Implementasi Pemberian Bantuan Hukum Bagi Rakyat Miskin Di Jawa Tengah Berdasarkan Undang-Undang Nomor 16 Tahun 2011 Tentang Bantuan Hukum. Jurnal Idea Hukum, 1(1).

Sarker, S. P. (2015). Empowering the underprivileged: The social justice mission for clinical legal education in India. In Clinical Legal Education in Asia (pp. 177-193). Palgrave Macmillan, New York.

Sentosa, A. (2012). Access to Justice Di Indonesia. Jakarta: Ditjen Badilag MARI.

Utari, I. W. (2014). Bantuan Hukum Secara Cuma-Cuma Bagi Tersangka atau Terdakwa Yang Tak Mampu. Jurnal Ius Utopia HukumKesejahteran, 2(1).

Winata, F. H. (2000). Bantuan Hukum: Sebuah Hak Asasi Manusia Bukan Belas Kasihan. Jakarta: PT. Elex Media Komputindo.

Winata, F. H. (2009). Pro Bono Publico: Hak Konstitusional Fakir Miskin Untuk Memeroleh Bantuan Hukum. Jakarta: PT Gramedia Pustaka Utama. 
Andjeng Pratiwi

\section{Legal Documents}

UU 14/1970 Tentang Ketentuan Pokok Kekuasaan Kehakiman.

Undang-Undang 39/1999 Tentang Hak Asasi Manusia.

Undang-Undang 50/2009 Tentang Peradilan Agama.

Undang-Undang 48/2009 Tentang Kekuasaan Kehakiman.

Undang-Undang 16/2011 Tentang Bantuan Hukum.

Peraturan Pemerintah 42/2013 Tentang Persaratan dan Tata Cara Bantuan Hukum serta Penyaluran Bantuan Hukum.

PERMA 1/2014 Tentang Pedoman Pemberian Layanan Hukum Untuk Masarakat Tidak Mampu di Pengadilan.

\section{Online Source}

https://pa-semarang.go.id

\section{Conflicting Interest Statement}

All authors declared that there is no potential conflict of interest on publishing this article.

\section{Funding}

None

Publishing Ethical and Originality Statement

All authors declared that this work is original and has never been published in any form and in any media, nor is it under consideration for publication in any journal, and all sources cited in this work refer to the basic standards of scientific citation.

Cite this article as:

Pratiwi, A. (2021). Providing Legal Aid in Facing Cases for Underprivileged Communities at the Religious Courts of Semarang City. The Indonesian Journal of International Clinical Legal Education, 3(3), 321-338. https://doi.org/10.15294/ijicle.v3i3.48271 